\title{
PEMAHAMAN \\ KESEHATAN REPRODUKSI BAGI PEREMPUAN: \\ Sebuah Strategi Mencegah Berbagai Resiko \\ Masalah Reproduksi Remaja
}

\author{
Hasyim Hasanah \\ Universitas Islam Negeri (UIN) Walisongo Semarang \\ e-mail: hasyimhasnah_82@yahoo.co.id
}

\begin{abstract}
Abstrak
Tulisan ini mendeskripsikan tentang strategi penanganan kasus kekerasan seksual pada perempuan melalui pemahaman kesehatan reproduksi bagi perempuan. Kesehatan reproduksi merupakan suatu kondisi sehat pada semua sistem organ, fungsi, dan proses reproduksi. Islam memiliki sikap sangat hati-hati terhadap upaya mencapai kesehatan reproduksi. Pendidikan kesehatan reproduksi amat penting untuk dilakukan, mengingat masih banyak remaja tidak memiliki pengetahuan yang akurat mengenai kesehatan reproduksi. Pendidikan tersebut juga diperlukan agar remaja dapat menghindari perilaku seks yang beresiko, yang membahayakan kesehatan reproduksi dan seksualnya. Pemahaman terhadap kesehatan reroduksi bagi remaja juga berfungsi sebagai strategi untuk menghindari tindak kekerasan seksual pada remaja.
\end{abstract}

Kata Kunci: kesehatan reproduksi; remaja; resiko masalah reproduksi

\section{A. Pendahuluan}

Globalisasi dengan kemajuan ilmu pengetahuan, industrialisasi dan modernisasi, telah mengakibatkan perubahan-perubahan sosial yang amat cepat. Perubahan sosial antara lain meningkatnya perilaku seks sebelum menikah, kehamilan di luar nikah yang dilakukan oleh remaja. Akibat berubahnya nilai-nilai kehidupan keluarga dan masyarakat menjadikan masa remaja menjadi masa yang tidak begitu menguntungkan. Terjadi kehamilan yang tidak diinginkan, praktik aborsi yang dapat membawa resiko kematian pada remaja. Rendahnya pemenuhan hak-hak reproduksi dapat diketahui dengan masih tingginya Angka Kematian Ibu (AKI), Angka Kematian Bayi (AKB) dan Angka Kematian Bawah Lima Tahun 
(AK Balita). Masalah kesehatan reproduksi bagi perempuan, termasuk perencanaan kehamilan dan persalinan yang aman secara medis juga harus menjadi perhatian bersama, bukan hanya kaum perempuan saja karena hal ini akan berdampak luas dan menyangkut berbagai aspek kehidupan yang menjadi tolok ukur dalam pelayanan kesehatan. Problem pemahaman mengenai kesehatan reproduksi juga dialami para remaja. Berdasarkan survey kependudukan tahun 2007, Indonesia masih memiliki angka pernikahan dini yang sangat tinggi dengan rata-rata 19,1 tahun usia pernikahan. Ini dikarenakan 20,9\% remaja perempuan telah hamil diluar nikah, 38,75 melakukan seks bebas. ${ }^{1}$ Survey kesehatan reproduksi remaja putri di beberapa kota besar menunjukkan selama tahun 2011 terdapat $41 \%$ telah melakukan hubungan seksual sebelum nikah.

Terdapat kenaikan yang cukup signifikan pada kasus aborsi yang dilakukan remaja perempuan. Kuntari menyebutkan bahwa di Indonesia angka abortus remaja perempuan mencapai 2-2,6 juta kasus pertahunnya atau sekitar 43 kasus aborsi setiap 100 kehamilan usia muda antara 15-24 tahun. ${ }^{2}$ Kasus lain berkaitan dengan problem penyakit menular seksual lainnya adalah meningkatnya jumlah angka penderita dengan HIV/AIDS. Tahun 2012 sebanyak 26.483 kasus HIV/AIDS terjadi pada kelompok usia muda antar 20-29 tahun. Tahun 2013 terdapat 29.031 kasus HIV/AIDS terjadi pada keompok usia muda. ${ }^{3}$

Data tingginya angka perniikahan dini, kasus hamil di luar nikah, tingkat aborsi, dan orang terinfeksi HIV/AIDS menunjukkan fakta yang memprihatinkan, terlebih realitas ini dialami kaum muda sebagai generasi bangsa. Remaja adalah masa penting dalam perjalanan kehidupan. Masa ini membutuhkan tanggung jawab secara sosial lebih tinggi untuk menuju pada masa dewasa dan kematangan. Idealnya remaja menjadi generasi yang membanggakan, benar-benar menikmati seluruh perjalanan masa remajanya dengan menyenangkan. Remaja belajar dengan segala hal secara sungguh-sungguh untuk mengembangkan segala potensi yang dimiliki.

'Zahrotul Uyun, "Peran Orang Tua dalam Pendidikan Kesehatan Reproduksi", Prosiding Seminar Nasional Parenting, 2013, h. 356.

2Titik Kuntari, Angka Kejadian Aborsi di Indonesia Tahun 2012, Fakultas Kedokteran UII Yogyakarta, 2012.

${ }^{3}$ Kementerian Kesehatan RI, "Data Orang dengan HIV/AIDS di Beberapa Daerah", Jakarta, 2013, h. 2. 
Namun banyak faktor yang menjadikan remaja justruu jauh dari pencapaian tugas perkembangan. Ini dibuktikan dengan masih rendahnya pemahaman remaja mengenai peran penting kesehatan reproduksi bagi kehidupannya, sehingga berdampak pada berbagai perilaku menyimpang yang membahayakan diri dan masa depannya. Maka dari itu, memberikan pemahaman mengenai kesehatan reproduksi bagi remaja mutlak diperlukan, agar remaja mampu memiliki kesadaran untuk menjaga memelihara dan menghindarkan diri dari tindak kekerasan seksual yang lebih dalam. Tulisan ini akan mendeskripsikan gambaran mengenai kesehatan reproduksi bagi remaja sebagai strategi menghindari kekerasa seksual pada remaja perempuan.

\section{B. Kesehatan Reproduksi}

Kesehatan reproduksi merupakan sustu kondisi sehat menyangkut sistem, fungsi, dan proses reproduksi. Kesehatan reproduksi merupakan suatu hal yang penting mengingat reproduksi adalah sarana untuk melahirkan generasi penerus bangsa.

\section{Kondisi Sehat}

Pengertian sehat tidak semata-mata berarti bebas dari penyakit atau kecacatan fisik, melainkan juga secara psikis, secara mental, sosial, dan kultural. ${ }^{4}$ Sehat secara fisik berarti suatu keadaan yang tidak sakit dan tidak memiliki cacaat secara fisik. Sehat bukan merupakan suatu kondisi saja, tetapi hasil dari proses penyesuaian. Artinya sehat bukan hanya dipahami sebagai suatu keadaan tapi merupakan proses menjadi sehat. Terdapat tiga karakteristik sehat menurut WHO, yaitu merefleksikan perhatian pada individu, memandang sehat dalam konteks lingkungan internal dan eksternal, dan hidup yang kreatif dan produktif. ${ }^{5}$ Kesehatan fisik adalah dalah adanya keadaan organ tubuh yang dapat berfungsi secara baik tanpa merasakan

${ }^{4}$ Badan Koordinasi keluarga Berencana Nasional, Proses Belajar Aktif Kesehatan Reproduksi Remaja, Jakarta: BKKBN, 2004, hlm. 7 ; lihat juga dalam UU Kesehatan No 23 tahun 1992; lihat juga dalam Undang-Undang kesehatan dan Rumah Sakit, Yogyakarta: Pustaka Yustisia, 2010, hlm. 7; lihat juga dalam ketentuan sehat menurut World Health Organization (WHO) dalam http://repository.usu.ac.id/bitstream/123456789/33995/4/ Chapter\%20I.pdf, diakses 28 Maret 2016

${ }^{5}$ https://fidahusain93.files.wordpress.com/2011/10/konsep-sehat-dan-sakit-paradigmakeperawatan-caring.pdf, diakses 28 Maret 2016. 
sakit atau keluhan dan memang secara objektif tidak tampak sakit. Semua organ tubuh dapat bekerja secara normal. ${ }^{6}$

Sehat secara psikis dan mental berarti didefinisikan sebagai kondisi yang memungkinkan indiviidu memahami potensi-potensinya yang mencakapup tiga komponen yaitu pikiran, emosional, dan spiritual. Sehat pikiran tercermin dalam berbaggai cara berfikir atau jalan fikir. Sehat emosional sehat tercermin dari bagaimana cara seseorang dalam mengekspresikan berbagai kondisi seperti sedih, bahagia, senang, dan lain-lain. Sehat spiritual tercermin dalam ekspresi keagamaan yang diekspresikan melalui ungkapan syukur, kepercayaan, pujian, terhadap Tuhan, melalui ibadah. Sehat secara sosial berarti terwujudnya interaksi setiap individu dengan sesama tanpa membedakan perbedaan suku, ras, maupun warna kulit, sehingga tercipta rasa toleransi dan persatuan. Sehat secara kultural berati terwujudnya kehidupan yang memiliki peradaban setiap individu dengan perbedaan suku, ras, maupun warna kulit, sehingga tercipta rasa toleransi dan persatuan.

Kesehatan reproduksi yang ada dalam konteks pembangunan masyarakat Indonesia mencakup 5 (lima) komponen/program terkait, yaitu Program Kesehatan Ibu dan Anak, Program Keluarga Berencana, Program Kesehatan Reproduksi Remaja, Program Pencegahan dan Penanggulangan Penyakit Menular Seksual (PMS) termasuk HIV/AIDS, dan Program Kesehatan Reproduksi pada Usia Lanjut. Pelaksanaan Kesehatan Reproduksi dilaksanakan dengan menggunakan pendekatan siklus hidup (life-cycle approach) agar diperoleh sasaran yang pasti dan pelayanan yang jelas berdasarkan kepentingan sasaran/klien dengan memperhatikan hak reproduksi. Kesehatan reproduksi memiliki tiga komponen yaitu kemampuan prokreasi, mengatur dan menjaga tingkat kesuburan, dan menikmati kehidupan seksual secara bertanggung jawab. Prioritas dari pelayanan kesehatan reproduksi pada konteks saat ini masih dalam hal kesehatan iibu dan anak (KIA), Keluarga Berencana (KB), kesehatan reproduksi Remaja (KRR) dan penanggulangan Pengakit Menular Seksual (PKMS).

${ }^{6}$ Heru Nurcahyo, Ilmu Kesehatan: Untuk Sekolah Menengah Kejuruan, Jakarta: Direktorat Pembinaan SMK Direktorat Jenderal Manajemen Pendidikan Dasar dan Menengah, 2008), h. 2. 
Masalah reproduksi remaja selain berdampak secara fisik, juga dapat berpengaruh terhadap kesehatan mental dan emosi, keadaan ekonomi dan kesejahteraan sosial dalam jangka panjang. Dampak jangka panjang tersebut tidak hanya berpengaruh terhadap remaja itu sendiri, tetapi juga terhadap keluarga, masyarakat dan bangsa pada akhirnya. Permasalahan kesehatan reproduksi pada remaja dapat dikelompokkan sebagai berikut: (1) perilaku berisiko, (2) kurangnya akses pelayanan kesehatan, (3) kurangnya informasi yang benar dan dapat dipertanggungjawabkan, (4) banyaknya akses pada informasi yang salah tanpa tapisan, (5) masalah PMS termasuk infeksi HIV/AIDS, (6) tindak kekerasan seksual, seperti pemerkosaan, pelecehan seksual dan transaksi seks komersial, (6) kehamilan dan persalinan usia muda yang berisiko kematian ibu dan bayi. dan (7) kehamilan yang tak dikehendaki, yang sering kali menjurus kepada aborsi yang tidak aman dan komplikasinya. Menurut Biran (1980) kehamilan remaja kurang dari 20 tahun berisiko kematian ibu dan bayi 2-4 kali lebih tinggi dibanding ibu berusia 20-35 tahun. Penyebab mendasar dari keadaan tersebut adalah: (a) rendahnya pendidikan remaja, (b) kurangnya keterampilan petugas kesehatan, (c) kurangnya kesadaran semua pihak akan pentingnya penanganan kesehatan remaja. ${ }^{7}$

\section{Sistem Organ Reproduksi}

Pada remaja, organ reproduksi mulai mengalami perkembangan dan pertumbuhan. Organ reproduksi meruupakan bagian tubuh seseorang yang digunakan untuk menjalankan reproduksi. Organ reproduksi adalah organ seksualitas baik pada laki-laki dan perempuan dibagian dalam maupun bagian luar tubuh manusia. Organ reproduksi pada laki-laki terdiri dari penis/buah zakar yang berfungsi sebagai alat melakukan senggama, mengeluakan air seni, dan sebagao jalan keluarnya sperma. Organ lainnya adalah kepala penis yang berda di ujung penis berupa lubang untuk menyalurkan air kencing dan sperma. Bagian ini sangat sensitif dan mudah terangsang karena memiliki banyak pembuluh darah. Bagian ketiga adalah kantong pelir yang terdiri dari biji pelir dan testi), serta sperma. Kantung pelir merupakan tempat biji testis. Testis memiliki fungsi sebagai tempat produksi sperma yang akan terbentuk karena hormone testosterone. Spema

${ }^{7}$ Departemen Kesehatan RI, Modul Kesehatan Reproduksi, Jakarta, 2001; lihat juga dalam Departemen Kesehatan RI, Pusat Penyuluhan Kesehatan, Strategi Penyuluhan, Jakarta, 1997. 
merupakan sel berbentuk seperti berudu berekor. Sperma dapat membuahi sel telur yang matang, dalam tubuh perempuan yang selanjutnya menyebabkan kehamilan. Saluran kemih merupakan organ reproduksi yang berfungsi menyalurkan air kencing dan air mani yang mengandung sperma. Epididimis berfungsi sebagai tempat mematangkan sperma yang dihasilkan testis. Saluran sperma berfungsi sebagai tempat menyalurkan sperma dari testis menuju prostat. Dan kelenjar prostat berfungsi menghasilkan air mani yang ikut mempengaruhi kesuburan sperma. ${ }^{8}$

Organ reproduksi pada perempuan terdiri dari ovarium, tuba volopi, uterus, vagina (kemaluan), selaput dara, bibir kemaluan, klitoris, saluran kemih. Ovarium adalah organ reproduksi yang berfungsi mengeluarkan sel telur. Tuba falopi berfungsi menyalurkan sel telur setelah keluar dari indung telur dan tempat terjadinya pembuahan. Uterus berfungsi sebagai tempat tumbuh dan berkembangnya tempat calon bayi. Vagina adalah lubang tempat masuknya sel sperma pada saat bersenggama. Vagina juga merupakan jalan keluarnya darah saat haid dan janin yang akan dilahirkan. Hymen merupakan lapisan tipis yang berada di dalam liang kemaluan. Bibir kemaluan adalah bagian paling luar yang memiliki banyak pembuluh darah. Klitoris adalah organ reproduksi yang memiliki tingkat kepekaan terhadap rangsangan yang sangat tinggi karena tersusun dari banyak pembuluh darah. Saluran kemih berguna untuk mengeluarkan air kencing dan terletak di antara klitoris dan mulut vagina. ${ }^{9}$

\section{Fungsi Kesehatan Reproduksi}

Fungsi memahami kesehatan reproduksi diantaranya adalah mengenal tubuhnya dan organ-organ reproduksinya; memahami fungsi dan perkembangan organ reproduksi secara benar. Memahami perubahan fisik dan psikisnya; melindungi diri dari berbagai risiko yang mengancam kesehatan dan keselamatannya; mempersiapkan masa depan yang sehat dan cerah; mengembangkan sikap dan perilaku bertanggungjawab mengenai proses reproduksi. ${ }^{10}$ Pada remaja, menganal bagian-bagian tubuh dan organ re-

${ }^{8}$ Rita Shintawati, "Kesehatan Reproduksi," dalam http://file.upi.edu/Direktori/ FPMIPA/JUR._PEND._BIOLOGI/196812012001122-RITA_SHINTAWATI/RITA-2/

KESEHATAN_REPRODUKSI.pdf, hlm. 6, diakses tanggal 27 Maret 2016.

${ }^{9} \mathrm{Ibid}, \mathrm{h} .7-8$.

${ }^{10} \mathrm{Ibid}, \mathrm{h} .4$. 
produksi menjadi hal yang sangat penting, karena dengan mengenal bagian biologis mengarahkan remaja untuk dapat berperilaku secara bertanggung jawab dalam menjaga tubuh dan organ reproduksinya. Memahami tubuh dan fungsi organ reproduksi secara benar tentu menjadikan remaja menjadi lebih berhati-hati dalam merawat, menjaga, dan melindungi organ reproduksinya. Pada tahap ini memungkinkan remaja memiliki kesadaran dalam melindungi aspek vital dan menjaga diri dari tindak kekerasan seksual.

Mempersiapkan masa depan yang sehat dan cerah dapat dilakukan dengan memelihara dan memahami masalah kesehatan reproduksi. Kondisi ini diarahkan pada upaya preventif bagi seorang remaja untuk mengembangkan organ reproduksinya secara matang, bebas dari cacat dan penyakit menular seksual lainnya, yang tentu akan berdampak pada masa depan. Remaja yang memiliki organ reproduksi yang sehat, tentu menjadikan kehidupan menjadi lebih indah dan bermakna, ceria dan bahagia, sebaliknya, remaja yang tidak mampu mencapai kondisi sehat pada organ reproduksinya, tentu akan mengalami hambatan dalam melahirkan generasi penerus, hidup cenderung susah, batin menjadi semakin resah dan tidak bahagia.

Remaja dengan sistem reproduksi yang sehat selalu berupaya untuk mengurasi resiko dan dampak negatif akibat problem kesehatan reproduksi. Melaksanakan kegiatan yang bersifat positif menjadi tanda bahwa remaja telah mampu memiliki tanggungjawab yang tinggi pada perkembangan organ reprosuksinya. Pada beberapa kondisi, sikap dan perilaku yang bertanggung jawab, menjadikan mampu melewati sebuah masa krisis yang menandai kedewasaan dan tingkat kematangan seksualnya.

\section{Proses Kehamilan di Usia Remaja}

Kehamilan adalah satu masa dimana seorang perempuan berhenti haid dan tumbuh dalam rahimnya seorang janin. Kehamilan terjadi karena terjadi pembuahan yaitu penggabungan sel sperma dan ovum dalam rahim seorang perempuan yang disebut fersilisasi. ${ }^{11}$ Kehamilan adalah proses berkembangnya embrio di dalam uterus sejak terjadi fertilisasi hingga dilahirkan. Waktu kehamilan manusia berkisar rata-rata 266 hari atau 38

${ }^{11} \mathrm{~A}$ sperm and egg join at fertilization, and the resulting zygote undergoes mitosis during development of the fetus". MoGraw-Hill, Higher Education, (New York: The McGraw-Hill Companies, 2007), h.177. 
minggu. Proses kehamilan dan kelahiran pada usia remaja memberikan kontribusi dalam meningkatkan angka kematian. Remaja hamil sering mengalami komplikasi seperti persalinan premature, berat badan bayi rendah, dan kematian prenatal, preeclampsia, penyakit menular seksual, malnutrisi, darah tinggi, dan solusio plasenta. ${ }^{12}$

Kehamilan hingga melahirkan adalah rangkaian proses reproduksi yang sangat berat yang harus dipikul oleh perempuan. ${ }^{13}$ Remaja hamil sering tidak menyadari masalah kesehatan reproduksi yang dialaminya, sehingga menempatkan diri dan bayinya ada pada kondisi resiko, gangguan penyakit, hingga kematian. Kehamilan juga merupakan masa yang membingungkan bagi remaja. Tubuhnya secara fisiologi mengalami perubahan yang tidak biasa dan sering menimbulkan ketakutan. Pada sebagian besar remaja, kehamilan menjadi situasi yang tidak diinginkan. Kondisi ini terbukti dengan semakin meningkatnya angka aborsi usia muda dari tahun ke tahun. Remaja yang aktif atau subur secara seksual, memiliki peluang $90 \%$ mengalami kehamilan.

Tingginya angka kehamilan dan aborsi dikalangan remaja perempuan disebabkan karena ketidaktahuan dan ketidaksadaran mengenai kondisi subur. Banyak mitos dan anggapan keliru para remaja bahwa kehamilan tidak akan terjadi pada saat pertama berhubungan seks, kehamilan tidak terjadi kalau laki-laki cepat-cepat menarik penisnya dari vagina, kehamilan tidak akan terjadi jika setelah berhubungan seks segera mencuci vagina. Fakta kehamilan bisa saja terjadi pada situasi tersebut. Ada anggapan budaya yang membicarakan atau menyampaikan informasi mengenai seks pranikah adalah hal tabu. Faktor ini juga menjadi salah satu penyebab ketidaktahuan dan ketidak sadaran remaja mengenai proses reproduksi. Remaja memiliki hak untuk mendapatkan pengetahuan dan pemahaman mengenai kehamilan, supaya memiliki tanggung jawab terhadap situasi dan kondisi yang sedang dialami. Remaja juga memahami status kesuburannya, sehingga tidak melakukan seks diluar pernikahan atau seks bebas. Banyak penyebab kehamilan diusia remaja diantaranya tekanan teman, pembuktian kejantanan, perasaan takut dan malu mengenai informasi seksual, keterlibatan media informasi, dan budaya masyarakat yang semakin meng-

\footnotetext{
${ }^{12}$ Jauharotul farida, dkk., "Kesehatan reproduksi di Pesantren", Modul Pendidikan Kesehatan Reproduksi Remaja, LPPM IAIN Walisongo, 2014, h. 82.

${ }^{13}$ D.A.Pratiwi, dkk, Buku Penuntun Biologi SMA 2, h. 204-205.
} 
global. Pada kasus kehamilan yang tidak diinginkan sering berakhir dengan aborsi dan kematian baik ibu maupun janin yang dikandungnya.

\section{Problem Kesehatan Reproduksi}

Problem kesehatan reproduksi yang dialami para perempuan dan remaja biasanya dikarenakan banyak faktor. Faktor penyebab munculnya problem reproduksi terdiri dari faktor yang bersifat internal, maupun eksternal. Faktaor yang bersifat internal terkait dengan persoalan pemahaman mengenai kesehatan reproduksi. Faktor yang bersifat ekternal bisanya merupakan faktor yang berhubungan dengan hal yang berada di luar kemampuan diri individu seperti lingkungan, pergaulanan, perkembangan teknologi informasi dan komunikasi, dan lain-lain. Faktor pemahaman mengenai kesehatan reproduksi menymbangkan kontribusi yang begitu besar terkait dengan persoalan-persoalan reproduksi remaja. Orang dengan pemahaman tentu mengarahkan dirinya untuk tidak melakukan faktor yang menyebabkan resiko dan dampak negatif bagi diri sendiri. Sebaliknya, remaja yang memiliki pemahaman rendah, cenderung kurang memiliki kepedulian, kesadaran dalam menjaga dan memelihara organ reproduksinya, yang selanjutnya sering berakhir pada terjadinya kekerasan seksual pada remaja.

Data yang dilansir oleh beberapa media online menyebutkan bahwa masih banyak remaja yang belum memahami kesehatan reproduksi, bagaimanakah fungsi organ reproduksi, bagaimana proses terjadinya reproduksi. Kecenderungan ini menyebabkan banyak remaja yang mengalami kekerasan seksual dan menjadi korban perilaku sek bebas.

\section{Kesehatan Reproduksi Menurut Islam}

Kesehatan dalam Islam merupakan syarat mendasar mendapatkan kebahagiaan dunia dan akhirat. Islam dalam konteks ini berfungsi tidak hanya sebatas aturan, melainkan pedoman yang mengatur segala kehidupan manusia dalam rangka kebahagiaan. Islam mengatur reproduksi yang sehat sebagai upaya memuliakan dan menjunjung derajat kemanusiaan. ${ }^{14}$ Salah satu bentuk kesehatan yang juga sangat diperhatikan Islam adalah

${ }^{14}$ Asih Widyowati, "Islam dan Kesehatan Reproduksi", 2009, h. 3 dalam laman www.fahmina.or.id/penerbitan/warkah-al-basyar/534-islam-dan-kesehatan-reproduksi. $\mathrm{html}$, diakses 27 Maret 2016. 
kesehatan reproduksi. Kesehatan reproduksi berkaitan dengan seksualitas dan pembentukan keluarga. ${ }^{15}$ Islam senantiasa mewajibkan para pemeluknya untuk menjaga kebersihan, baik kebersihan jasmani maupun ruhani, lahir maupun batin. ${ }^{16}$ Kesehatan jasmani dengan kesehatan rohani merupakan kesatuan sistem terpadu, sebab kesehatan jasmani dan rohani menjadi syarat bagi tercapainya suatu kehidupan yang sejahtera di dunia dan kebahagiaan di akhirat. Islam sebagai pedoman hidup tentunya memiliki kaitan erat dengan kesehatan reproduksi mengingat Islam memiliki aturanaturan dalam kehidupan manusia yang bertujuan untuk mencapai kondisi yang sesuai dengan persyaratan kesehatan reproduksi.

Menjaga kebersihan fisik merupakan hal mendasar bagi seorang Muslim karena mendasarkan pada kaidah yang menyebutkan bahwa di dalam hidup yang sehat terdapat jiwa yang kuat. Imam muslim menyebutkan bahwa kesucian adalah setengah dari iman. Ini membuktikan bahwa begitu pentingnya kesucian dalam ajaran Islam. Perintah menjaga kesucian mencakup perintah untuk selalu menjaga kebersihan, dan kebersihan adalah tanda keimanan seseorang. Kesehatan reproduksi dalam islam berkaitan dengan kebersihan. Kebersihan jasmani lainnya berkaitan dengan perintah untuk menjaga kebersihan hati dengan menikah. Menikah adalah perintah bagi laki-laki dan perempuan yang telah mencapai usia dewasa. Menikah adalah salah satu bentuk perlindungan pada organ reproduksi secara lebih sehat dan bertanggung jawab. Setiap orang berhak dalam mengatur jumlah keluarganya, termasuk memperoleh penjelasan yang lengkap tentang cara-cara kontrasepsi sehingga dapat memilih cara yang tepat dan disukai. Selain itu, hak untuk mendapatkan pelayanan

${ }^{15}$ Kesehatan reproduksi dan persiapan keluarga dalam pemahaman ini mencakup empat kategori yaitu 1) Hak seseorang untuk dapat memperoleh kehidupan seksual yang aman dan memuaskan serta mempunyai kapasitas untuk bereproduksi; 2) Kebebasan untuk memutuskan bilamana atau seberapa banyak melakukannya; ) Hak dari laki-laki dan perempuan untuk memperoleh informasi serta memperoleh aksebilitas yang aman, efektif, terjangkau baik secara ekonomi maupun kultural; 4) Hak untuk mendapatkan tingkat pelayanan kesehatan yang memadai sehingga perempuan mempunyai kesempatan untuk menjalani proses kehamilan secara aman; lihat dalam Tuslim Ibrahim, Kesehatan Reproduksi dan Perencanaan Keluarga Menurut Figh, (Aceh: MPU Aceh, tth.), h. 2.

${ }^{16}$ Duski Samad, "Pandangan Islam tentang Hak Kesehatan Seksual dan Reproduksi" dalam http://tarbiyahiainib.ac.id/dekan/artikel/601-pandangan-islam-tentang-hak-kesehatanseksual-dan-reproduksi, diakses 27 Maret 2016 
kesehatan reproduksi lainnya, pelayanan antenatal, persalinan, nifas, dan pelayanan bagi anak, dan kesehatan remaja perlu dijamin.

Menurut Asruddin, Islam memandang aktivitas seksual sebagai aktivitas yang suci dan merupakan fitrah manusia. ${ }^{17}$ Aktivitas seksual dalam pengertian sebagai fitrah yang suci dimaksudkan karena seksualitas dilakukan dalam lingkup hubungan yang sesuai syariat, yaitu hubungan pasangan laki-laki dan perempuan bukan antara pasangan sejenis (homoseksual) atau dengan binatang (zoofilia) yang telah menikah secara sah. Aktivitas seksual menjadi sarana penjaga kesinambungan eksistensi umat manusia di dunia dan juga sebagai sarana kesenangan bagi manusia seperti dalam QS. al-Rum ayat 21.

"Dan diantara tanda-tanda kekuasaan-Nya ialah Dia menciptakan untukmu isteri-isteri dari jenismu sendiri, supaya kamu cenderung dan merasa tentram kepadanya, dan dijadikan-Nya di antara kamu rasa kasih dan sayang. Sesungguhnya pada yang demikian itu benarbenar terdapat tanda-tanda bagi kaum yang terpelajar." (QS al-Rum: 21)

Ativitas seksual dalam pengertian ini menunjuk pada persoalan pencapaian tujuan kebahagiaan, juga menjadi sarana mendekatkan diri kepada Allah. Seksualitas menjadi hak reproduksi bagi manusia yang bernilai ibadah. Hubungan seksual tidak hanya sekedar kewajiban antara laki-laki dan atau perempuan, tetapi menjadi sarana untuk bertakwa kepada Allah atas kenikmatan yang telah diberikan. Pada orang yang sudah menikah, akan disempurnakan agamanya dan ibadahnya.

"Dua rakaat shalat yang didirikan oleh orang yang kawin lebih baik daripada keterjagaan (ibadah) di malam hari dan puasa (disiang hari) orang yang tidak kawin." (HR. al-Thabrani)

Islam memahmi bahwa kegiatan reproduksi berkaitan dengan proses penciptaan manusia. Manusia sesuai dengan fitrahnya dibekali kemampuan untuk berkembang biak meninggikan dan menyebarkan agama Allah. Reproduksi pada manusia mengahantarkan terbentuknya individu baru,

\footnotetext{
${ }_{17}$ M. Asrorudin, “Islam dan Kesehatan Reproduksi", 2009, www.asroruddin.multiply. com/journal/item/33/Islam_dan_Kesehatan_Reproduksi.html

http://rifkihidayat08.blogspot.co.id/2013/11/reproduksi-menurut-ajaran-islam.html, diakses 9 April 2016
} 
keluarga baru, dan kelompok masyarakat baru. Dan Proses reproduksi pada manusia adalah sebaik-baik penciptaan..$^{18}$

"Yang membuat segala sesuatu yang Dia ciptakan sebaik-baiknya dan Yang memulai penciptaan manusia dari tanah. Kemudian Dia menjadikan keturunannya dari sari pati air yang hina (air mani). Kemudian Dia menyempurnakan dan meniupkan ke dalam (tubuh) nya roh (ciptaan)-Nya dan Dia menjadikan bagi kamu pendengaran, penglihatan dan hati; (tetapi) kamu sedikit sekali bersyukur" (QS. alSajdah: 7-9)

"Bukahkah dia dahulu setetes mani yang ditumpahkan (kedalam rahim), kemudian mani itu menjadi segumpal darah, lalu Allah menciptakannya, dan menyempurnakannya, lalu Allah menjadikan darinya sepasang laki-laki dan perempuan" (QS. al-Qiyamah: 37-39)

"Kemudian air mani itu Kami jadikan segumpal darah, lalu segumpal darah itu Kami jadikan segumpal daging, dan segumpal daging itu Kami jadikan tulang belulang, lalu tulang belulang itu Kami bungkus dengan daging. kemudian Kami jadikan Dia makhluk yang (berbentuk) lain. Maka Maha sucilah Allah, Pencipta yang paling baik."

"Hai manusia, jika kamu dalam keraguan tentang kebangkitan (dari kubur), Maka (ketahuilah) Sesungguhnya Kami telah menjadikan kamu dari tanah, kemudian dari setetes mani, kemudian dari segumpal darah, kemudian dari segumpal daging yang sempurna kejadiannya dan yang tidak sempurna, agar Kami jelaskan kepada kamu dan Kami tetapkan dalam rahim, apa yang Kami kehendaki sampai waktu yang sudah ditentukan, kemudian Kami keluarkan kamu sebagai bayi, kemudian (dengan berangsur- angsur) kamu sampailah kepada kedewasaan, dan di antara kamu ada yang diwafatkan dan (adapula) di antara kamu yang dipanjangkan umurnya sampai pikun, supaya Dia tidak mengetahui lagi sesuatupun yang dahulunya telah diketahuinya. dan kamu Lihat bumi ini kering, kemudian apabila telah Kami turunkan air di atasnya, hiduplah bumi itu dan suburlah dan menumbuhkan berbagai macam tumbuh-tumbuhan yang indah." (QS. al-Hajj: 5)

Ayat-ayat di atas menunjukkan bahwa Allah menganugerahkan kemampuan reproduksi pada manusia sebagai bentuk bukti kasih sayang,

${ }^{18}$ Zahrotul Uyun, "Peran Orang Tua dalam Pendidikan Kesehatan Reproduksi”, h. 362 
bentu ketakwaan. Melahirkan keturunan untuk mengelola bumi dan menjadi khalifah di dunia.

Kesehatan reproduksi dalam islam juga berkaitan dengan mekanisme system reproduksi itu sendiri yaitu masa kehamilan dan menstruasi atau haid. Menstruasi atau haid dialami oleh perempuan yang sehat. Perempuan yang ada pada masa haid menunjukkan bahwa organ reproduksinya berjalan sesuai dengan fungsinya, dan menjadi pertanda perempuan memasuki masa subur. ${ }^{19}$ Perempuan yang sedang menngalami haid, berarti tidak sedang hamil. Islam member batasan yang tegas pada aktivitas seksual yang akan dilakukan pada masa haid. Laki-laki maupun perempuan mendapat batasan mengenai aktivitas seksual pada masa haid, karena memiliki dampak negatif seperti QS. al-Baqarah 222-223.

"Mereka bertanya kepadamu tentang haid. Katakanlah, "haid itu adalah kotoran. Oleh karena itu hendaklah kamu menjauhi diri dari wanita di waktu haid; dan janganlah kamu mendekati mereka sebelu mereka suci. Apabila mereka telah suci, maka campurilah mereka itu ditempat yang diperintahkan Allah kepadamu. Sesungguhnya Allah menyukai orang-orang yang bertobat dan menyukai orang-orang yang mensucikan diri. Isteri-isterimu adalah (seperti) tanah tempat kamu bercocok tanam, maka datangilah tanah tempat bercocok tanammu itu sebagaimana saja kamu kehendaki. Dan kerjakanlah (amal yang baik) untuk dirimu, dan bertaqwalah kepada Alah dan ketahuilah bahwa kamu kelak akan menemui-Nya. Dan berilah kabar gembira orang-orang yang beriman" (QS al-Baqarah: 222-223)

Haid merupakan darah kotor. Bagi Allah memerintahkan pada setiap suami untuk menjauhkan diri dari istri mereka, memiliki arti tidak melakukan hubungan suami istri. Ayat tersebut memberikan batasan secara jelas, mengandung makna bahwa haid suatu proses reproduksi yang dialami setiap wanita. Melakukan hubungan dengan perempuan yang sedang dalam masa haid, berdampak kepada gangguan kesehatan reproduksi (baik laki-laki maupun perempuan). Apabila dalam hubungan tersebut terjadi pembuahan, maka anak yang akan dilahirkan dapat menjadi cacat.

Kesehatan reproduksi berkaitan dengan kehidupan keluarga yang sehat dan bertanggung jawab, bahagia dan sejahtera. Masing-masing pihak

${ }^{19}$ Nurdeni Dahri, Reproduksi Perempuan dalam Perspektif Islam (Tinjauan terhadap Haid, Nifas, dan Istihadhah), Kanwil Kementrian Agama Provinsi Riau, t.th., h. 3. 
berusaha memberikan yang terbaik untuk keberlangsungan kehidupannya. Kehidupan yang baik dan bertanggung jawab harus dimulai dari ikatan perkawinan yang sah sesuai dengan ajaran agama.

"Maka hendaklah manusia memperhatikan dari apakah dia diciptakan, Dia diciptakan dari air yang terpancar, yang keluar dari antara tulang sulbi dan tulang dada" (QS al-Thariq: 5-7)

Perkawinan atau pernikahan adalah satu-satunya sarana yang sah, halal, bagi pemenuhan kebutuhan seksual dan reproduksi. Islam memiliki pandangan yang sangat hati-hati mengenai penyaluran hasrat seksualitas. Hasrat seksual merupakan kebutuhan dasar (basic need) seorang manusia yang kedudukannya sama seperti kebutuhan makan dan minum seperti firman Allah dalam QS Ali Imran ayat 14.

"Dijadikan indah pada (pandangan) manusia kecintaan kepada apaapa yang diingini, Yaitu: wanita-wanita, anak-anak, harta yang banyak dari jenis emas, perak, kuda pilihan, binatang-binatang ternak ${ }^{20}$ dan sawah ladang. Itulah kesenangan hidup di dunia, dan di sisi Allah-lah tempat kembali yang baik (surga). (QS. Ali Imran: 14)

Penyaluran seksual harus sesuai aturan agama yaitu melalui ikatan pernikahan, dengan hubungan heteroseks, tidak dengan hewan dan mayat.

"Sesungguhnya kalian mendatangi lelaki untuk melepaskan nafsu kalian (kepada mereka), bukan kepada wanita, kalian adalah kaum yang melampaui batas"(QS. Al-A'raf: 81).

Memenuhi kebutuhan seksual diluar ikatan perkawinan adalah dosa. Seksualitas dalam Islam dapat menjadi hal yang tercela jika hubungan dilakukan di luar pernikahan, antara pasangan sejenis, atau dengan binatang. Kekhawatiran Islam tentang hal ini sangat beralasan mengingat banyak ditemukan penyimpangan-penyimppangan di masyarakat yang berakibat pada timbulnya penyakit-penyakit menular seksual dan desakralisasi hubungan pernikahan dimana hanya mementingkan syahwat.

"Dan tidaklah patut bagi laki-laki yang beriman dan tidak (pula) bagi perempuan yang beriman, apabila Allah dan Rasul-Nya telah me-

${ }^{20}$ Yang dimaksud dengan binatang ternak di sini ialah binatang-binatang yang Termasukjenis unta, lembu, kambing dan biri-biri. 
netapkan suatu ketetapan, akan ada bagi mereka pilihan (yang lain) tentang urusan mereka. Dan barang siapa yang mendurhakai Allah dan RasulNya, maka sesungguhnya ia telah sesat, sesat yang nyata (QS. al-Ahzab: 36)

Dalam Islam, bukan hanya perzinahan yang harus dihindari, segala sesuatu yang mendekati (berpotensi) menggiring kepada perzinahan juga harus dihindari.

"Dan janganlah kamu mendekati zina, sesungguhnya zina itu adalah suatu perbuatan yang keji, dan suatu jalan yang buruk" QS. al-Isra': 32).

Berzina memiliki dampak yang begitu luarbiasa. Tidak hanya dampak personal, menainkan dampak sosial, ekonomi, dan moral. Dampak personal menjadikan pezina menjadi pribadi yang liar, tidak terkendali, memiliki kkarakter seperti hewan. Dampak secara sosial dapat merusak struktur tatanan sosial, menimbulkan keresahan, kekacauan, dan rasa tidak aman. Dampak psikologis berupa rasa penyesalan, rasa bersalah, dan berdosa, sikap mental yang terganggu. Dampak material berupa kemelaratan, kemiskinan, dan kerugian. Dampak secara moral berupa sangsi moral masyarakat, dikucilkan, dipinggirkan, dan diisolasi dari kehidupan sosial.

Islam memberi banyak ruang dan dukungan akses kesehatan reproduksi terutama pada bagi perempuan. Islam sangat memuliakan kaum perempuan terutama ibu. Posisi perempuan harus dijaga lewat normanorma sosial. Pemahaman yang benar mengenai kesehatan reproduksi merupakan salah satu bentuk dukungan Islam agar kaum perempuan dapat menjadi ibu yang sehat dan bertanggung jawab. ${ }^{21}$ Umat Islam, baik laki-laki maupun wanita, sebaiknya mau belajar lebih banyak mengenai kesehatan reproduksi agar norma-norma sosial dalam Islam bisa ditegakkan dan dijalankan secara harmonis dengan ajaran-ajaran Islam lainnya. Kesehatan reproduksi adalah amanah kehidupan. Allah menciptakan manusia melalui kehamilan, yang dalam proses menjadi manusia utuh harus dijaga dengan baik.

${ }^{21}$ ToR, Lokakarya Hak Kesehatan Seksual dan Reproduksi (HKSR) bagi Tokoh Adat dan Tokoh Agama di Kota Padang. LP2M, 20-21 Mei 2015, dalam http:/tarbiyahiainib.ac.id/ dekan/artikel/601-pandangan-islam-tentang-hak-kesehatan-seksual-dan-reproduksi, diakses 27 Maret 2016 


\section{E. Faktor yang Mempengaruhi Kesehatan Reproduksi}

Kesehatan reproduksi pada remaja dipengaruhi beberapa faktor. Faktor tersebut diantaranya: kepantasan hubungan seksual di kalangan remaja; bagaimana cara melakukan pemenuhan kebutuhan seksual yang sehat; bagaimana cara mengakses jasa serta informasi terkait kesehatan seksual dan reproduksi; derajat tingkat perilaku yang dipengaruhi oleh kurangnya pengetahuan; pengaruh masyarakat dan budaya menyimpang; bagaimana cara mengendalikan kesuburan secara efektif. ${ }^{22}$ Masing-masing faktor memiliki tingkat yang berbeda dalam mempengaruhi kesehatan reproduksi pada remaja.

Faktor lain yang diduga juga menjadi pemicu munculnya problem kesehatan reproduksi dibagi menjadi empat, diantaranya faktor biologis, psikologis, sosial dan ekonomi, serta budaya dan lingkungan. Faktor biologis berupa kondisikecacatan (kecacatan sejak lahir, cacat saluran reproduksi), dan penyakit menular seksual. Faktor psikologis berupa beban psikis akibat dampak broken home bagi remaja, ketidaknormalan hormone, rasa tidak berharga, tidak percaya diri, merasa bersalah, dan lain sebagainya. Faktor sosial dan ekonomi dikombinasikan dengan demografi dalam bentuk kemiskinan, tingkat pendidikan yang rendah, ketidaktahuan informasi perkembangan seksual dan reproduksi, atau lokasi dan kawasan tertinggal. Faktor budaya dan lingkungan dapat berupa praktik kebiasaan, praktik tradisional yang berakibat pada reproduksi, mitos banyak anak banyak rejeki, informasi tentang fungsi reproduksi yang membingungkan.

\section{F. Faktor Kekerasan Seksual pada Remaja Perempuan}

Kekerasan seksual dipahami sebagai segala bentuk perilaku yang berkonotasi seksual. Kekerasan seksual dilakukan sepihak dan tidak diinginkan oleh orang yang menjadi korbannya. Pemahaman mengenai kekerasan seksual mencakup pada bentuk pelecehan seksual sampai memaksa untuk melakukan hubungan seksual tanpa persetujuan korban atau melakukan hubungan seksual dengan cara-cara tidak wajar atau tidak disukai korban, atau menjauhkannya dari kebutuhan seksualnya. Bentuk-bentuk kekerasan seksual diantaranya aktivitas menyentuh, meraba, mencium, memaksa

${ }^{22}$ Eny Kusmiran, Reproduksi Remaja dan Wanita, (Jakarta: Salemba Medika, 2012), h. 4. 
korban melihat pornografi, gurauan seksual yang tidak dikehendaki korban, ucapan yang merendahkan, melecehkan, atau menyakiti korban. Kekerasan seksual ini dapat dialami oleh laki-laki maupun perempuan, mulai dari usia anak-anak sampai usia dewasa. ${ }^{23}$

Kekerasan seksual terhadap perempuan disebabkan oleh dominasi lakilaki dalam menempatkan diri sebagai bagian dari kelompok masyarakat. Kedudukan laki-laki mengendalikan seksualitas dan identitas gender pada perempuan. Laki-laki dalam praktiknya memberlakukan mekanisme kontrol terhadap perempuan yang disebut sebagai seksual terrorism. Sexual terrorism merupakan salah satu bentuk dari sistem ideologi yang dilakukan oleh laki-laki terhadap perempuan dalam rangka mendominasi dan mengontrol perempuan melalui kekerasan. Al-Khayyat menyebutkan bahwa terdapat beberapa negara yang memperkerjakan perempuan dalam pengaturan kondisi seksual dan menerima mereka untuk mengandung dan melahirkan. ${ }^{24}$

Kekerasan seksual dalam praktiknya dikatakan memiliki intensitas paling ringan adalah pelecehan seksual. ${ }^{25}$ Pelecehan seksual berupa siulan nakal, kerdipan mata, gurauan dan olok-olok yang menjurus pada seks, memandangi tubuh mulai ujung rambut sampai ujung kaki. Bentuk lainnya seperti pernyataan mengenai tubuh atau penampilan fisik, memberikan bahasa isyarat yang berkonotasi seksual, memperlihatkan gambar-gambar porno, memperlihatkan organ seks, mencolek, serta meraba atau mencubit.

\section{G. Upaya Mencapai Kesehatan Reproduksi bagi Remaja}

Setiap remaja mempunyai hak untuk mendapatkan akses dan informasi tentang kesehatan reproduksi berupa pendidikan reproduksi dan seks. ${ }^{26}$ Pendidikan seks tidak ditujukan untuk mengajarkan mereka tentang hubungan seks, namun memberi pengetahuan tentang upaya yang perlu

${ }^{23}$ Sri Suhandjati, Islam menentang Kekerasan Terhadap Istri, Yogyakarta: Gama Media, 2004, h. 7-9.

${ }^{24}$ Muhammad Haitsam al-Khayyath, Problematika Muslimah di Era Modern, h. 96.

${ }^{25}$ Sugihastuti Itsan Hadi Saptiawan, Gender dan Inferioritas Perempuan, Yogyakarta: Pustaka Pelajar, 2010, hlm. 204

26 ICPD, "Konferensi Internasional Kependudukan dan Pembangunan di Kairo", Makalah konferensi Internasional, Kairo Mesir, 1994, hlm. 7 dalam Diffah Hanim, Santosa, dan Affandi, Kesehatan reproduksi, Modul Field lab, Field Lab Fakultas Kedokteran Universitas Sebelas Maret, 2013, hlm. 4 
mereka tempuh untuk menjaga kesehatan organ reproduksi. Kesehatan reproduksi bagi remaja berarti memiliki informasi yang benar dan tepat mengenai fungsi, peran, dan proses reproduksi. Pendidikan kesehatan reproduksi juga mengarahkan pada remaja untuk memiliki sikap serta tingkahlaku bertanggung jawab mengenai proses reproduksi. Prinsip dasar dalam mencapai kesehatan reproduksi secara fisik berkaitan dengan usaha menjaga kebersihan. Ada dua jenis menjaga kebersihan yaitu menjaga kebersihan diri dan menjaga kebersihan organ reproduksi. Menjaga kebersihan diri adalah proses membersihkan dan menjaga diri untuk tetap bersih, tidak kotor, dan terhindar dari penyakit. Ini dapat dilakukan dengan mandi rutin dua kali sehari, mencukupi kebutuhan gizi dan asupan makanan, menjaga berat badan ideal, membersihkan hati dan berusaha hidup bahagia.

Menjaga kebersihan organ reproduksi dilakukan dengan cara (1) menjaga kesehatan vagina dimulai dari memperhatikan kebersihan diri. Indonesia merupakan daerah yang beriklim tropis. Udara panas dan cenderung lembab sering membuat banyak berkeringat. Terutama dibagian tubuh yang tertutup dan lipatan-lipatan kulit, seperti daerah alat kelamin. Kondisi ini dapat menyebabkan mikroorganisme jahat, terutama jamur mudah berkembang biak, yang akhirnya bisa menimbulkan infeksi; (2) mengganti celana dalam minimal dua kali sehari; (3) Membersihkan kotoran yang keluar dari alat kelamin atau anus dengan menggunakan air bersih atau kertas pembersih (tisu); (4) gerakkan cara membersihkan alat kelamin adalah dari arah vagina kearah anus, untuk mencegah kotoran anus masuk ke vagina; (5) tidak menggunakan air yang kotor untuk membersihkan vagina; (6) dianjurkan untuk mencukur atau merapikan rambut kemaluan karena bisa ditumbuhi jamur atau kutu yang dapat menimbulkan rasa gatal dan tidak nyaman ${ }^{27}$; (7) pada siklus menstruasi, remaja perempuan mengganti pembalut setiap tiga hingga empat jam sekali.

\section{H. Pendidikan Kesehatan reproduksi dan Strategi Penanganan Kekerasan Sexual}

Berdasarkan pada data dari Kejaksaan Agung selama tahun 2006 terdapat 600 kasus kekerasan terhadap anak (KTA) yang telah diputus oleh

${ }^{27}$ Eny Kusmiran, Reproduksi Remaja dan Wanita, h. 23. 
kejaksaan. Data dari Komisi Perlindungan Anak Indonesia (KPAI) menunjukkan analisis 19 surat kabar nasional yang terbit di Jakarta bahwa selama tahun 2007 terdapat 455 kasus kekerasan terhadap anak. Sementara Komnas Perlindungan Anak mencatat, selama tahun 2007 praktik KTA mengalami peningkatan 300 persen dari tahun sebelumnya. ${ }^{28}$ Data pengaduan KPAI sejak tahun 2011 menunjukkan bahwa terdapat 329 kasus kekerasan, pada tahun 2012 naik menjadi 746 kasus, dan pada tahun 2013 menjadi 525 kasus, atau setara dengan rata-rata 45 anak mengalami kekerasan seksual setiap bulannnya. Korban kekerasan seksual pada anak diketahui $60 \%$ adalah anak laki-laki dan $40 \%$ anak perempuan. Sementara dari Januari hingga Maret 2014, KPAI sudah menerima pengaduan hingga 379 kasus. Data ini menunjukkan bahwa anak-anak korban kejahatan seks tentunya bukan hanya menderita secara fisik, tapi juga psikis, bahkan memiliki dampak yang lebih parah ketimbang orang dewasa. Seorang anak mengalami kejahatan seksual, bisa menjadi sangat trauma atau justru menikmatinya. Kedua kondisi ini sama-sama berperan dalam merusak masa depan anak..$^{29}$

Situasi kekerasan seksual butuh untuk ditangani secara tepat, agar dampak kekerasan seksual tidak menjadi kehancuran bagi perkembangan masa depan remaja. Melalui pemahaman, penanaman kesadaran reproduksi diyakini dapat mengurangi dampak terjadinya tindak kekerasan terhadap remaja. Islam secara komprehensif telah memberikan prinsip dasar mengenai usaha penyelamatan reproduksi bagi remaja. Hasanah menyebutkan bahwa dalam Islam mencegah lebih baik dari mengobati. ${ }^{30} \mathrm{Mem}-$ berikan pemahaman dan informasi yang tepat dan benar mengenai kesehatan reproduksi dan keyakinan nilai-nilai ajaran agama merupakan strategi preventif bagi remaja. Menanamkan nilai-nilai keagamaan sedini mungkin menjadikan benteng pelindung bagi anak menjadi lebih kokkoh dan efektif. Pemahaman dan informasi kesehatan reproduksi juga dapat diperoleh melalui pendidikan kesehatan reproduksi. Bagi remaja persoalan seksualitas merupakan hal yang sangat menantang dan membuat rasa

${ }^{28}$ Melindungi Anak dari Seks Bebas, Jakarta: Raja Grasindo, 2010, h. 19.

${ }^{29}$ Sutanto, "kenali predator seksual di sekitar kita", dalam ttp:/www.getscoop.com/ berita/kenali-predator-seksual-di-sekitar-kita/, diakses 23 Maret 2016

${ }^{30}$ Hasyim Hasanah, Pengantar Studi Islam, (Yogyakarta: Ombak, 2013), h. 53. 
penasaran yang begitu besar. Kondisi ini terjadi karena masa remaja merupakan salah satu bagian fase kehidupan manusia yang penuh gejolak. Remaja mengalami perkembangan emosi, biologis, dan sosial, yang membuatnya menjadi rentan menghadapi persoalan. Pendidikan kesehatan reproduksi menjadi hal penting dalam perkembangan tersebut. Pentingnya pemahaman atas pendidikan kesehatan reproduksi bagi remaja paling tidak mengenai informasi seksual remaja yang sebenarnya, remaja akan memiliki kesadaran pentingnya memahami masalah seksualitas. Pendidikan kesehatan reproduksi juga akan memunculkan pemahaman dan kesadaran mengenai fungsi-fungsi seksualnya, memahami masalah seksualitas remaja, dan memahami faktor-faktor yang menyebabkan timbulnya problem kekerasan seksual.

Ketidakpahaman remaja mengenai seksualitas dan kesehatan organ reproduksinya disebabkan karena faktor budaya dan lingkungan yang begitu menanggap aktivitas seksual sebagai hal tabu. Budaya dan lingkungan yang tidak kondusif, menjadikan remaja ingin menemukan dan mencoba sesuatu yang baru. Ketidakpahaman remaja menyebabkan rasa kurang bertanggung jawab dengan seks dan kesehatan reproduksi. Pengaruh budaya, lingkungan, serta perkembangan ilmu pengetahuan dan teknologi yang tanpa batas, menyebabkan akses informasi menjadi sangat nyata. Ini menjadikan remaja berusaha mencari fantasi seksual yang tidak pernah didapatkan dari keluarga atau saudaranya. Kondisi ini menjadikan remaja menjadi korban konsumtif dari tayangan dan informasi yang mengarah pada bentuk penyimpangan seksualitas pada usia remaja. Akibat yang lebih besar adalah hubungan sex bebas dan hamil di luar nikah, kehamilan yang tidak diinginkan, penularan penyakit menular seksual mematikan.

\section{Kesimpulan}

Kesehatan reproduksi merupakan hal penting dalam kehidupan. Islam memerintahkan semua umatnya untuk mencapai kebahagiaan hidup yang diawali dari kesehatan. Baik kesehatan fisik, maupun non fisik, kesehatan jasmani maupun rohani salah satunya kesehatan reproduksi. Kesehatan reproduksi adalah amanah dari Allah untuk melahirkan generasi yang berkualitas dan sehat. Persoalan kesehatan reproduksi bisanya terjadi pada usia awal, yaitu remaja. Masa ini menjadi masa yang berisiko pada masalah kesehatan reproduksi seperti seks bebas, seks di luar pernikahan, kehamilan 
yang tidak diinginkan, aborsi, kekerasan seksual, bahkan sampai pada kematian ibu dan anak. Banyak remaja yang terjebak pada persoalan ini, yang dibuktikan dengan semakin meningkatnya kasus pemerkosaan, hamil diluar nikah, aborsi, kekerasan seksual dan kematian ibu dan anak karena ketidak siapan ramin pada waktu hamil pertama. Remaja umumnya memiliki informasi yang rendah, serta pemahaman yang kurang mengenai kesehatan reproduksi. Hal ini karena banyak anggapan bahwa mengetahui masalah seksualitas masih dianggap tabu dan jorok. Maka para remaja membutuhkan pendidikan dan informasi mengenai kesehatan reproduksi agar memiliki pengetahuan yang cukup mengenai reproduksi, bagaimana fungsi-fungsi organ bekerja, bagaimana kehamilan, dan dampak yang ditimbulkannya.]

\section{Daftar Pustaka}

Badan Koordinasi keluarga Berencana Nasional, Proses Belajar Aktif Kesehatan Reproduksi Remaja, Jakarta: BKKBN, 2004.

Dahri, Nurdeni "Reproduksi Perempuan dalam Perspektif Islam (Tinjauan terhadap Haid, Nifas, dan Istihadhah)", Kanwil Kementrian Agama Provinsi Riau, t.th.

Departemen Kesehatan RI, Modul Kesehatan Reproduksi, Jakarta, 2001.

Departemen Kesehatan RI, Pusat Penyuluhan Kesehatan, Strategi Penyuluhan, Jakarta, 1997.

Farida, Jauharotul, dkk., "Kesehatan reproduksi di Pesantren", Modul Pendidikan Kesehatan Reproduksi Remaja, LPPM IAIN Walisongo, 2014.

Hanim, Diffah, Santosa, dan Affandi, "Kesehatan Reproduksi", Modul Field lab, Field Lab Fakultas Kedokteran Universitas Sebelas Maret, 2013.

Hasanah, Hasyim, Pengantar Studi Islam, Yogyakarta: Ombak, 2013.

Ibrahim, Tuslim, Kesehatan Reproduksi dan Perencanaan Keluarga Menurut Fiqh, Aceh: MPU Aceh, t.th.

ICPD, "Konferensi Internasional Kependudukan dan Pembangunan di Kairo", Makalah konferensi Internasional, Kairo Mesir, 1994.

al-Khayyath, Muhammad Haitsam, Problematika Muslimah di Era Modern, Jakarta: Erlangga, 2007. 
Kementerian Agama RI, al Quran dan Terjemahannya, Jakarta: Lajnah Pentahshih al-Qur'an, 2012.

Kementerian Kesehatan RI, Data Orang dengan HIV/AIDS di Beberapa Daerah, Jakarta, 2013.

Ketentuan Sehat menurut World Health Organization (WHO) dalam http://repository.usu.ac.id/bitstream/123456789/33995/4/Chapter\%20II. pdf, diakses 28 Maret 2016.

Kuntari, Titik, Angka Kejadian Aborsi di Indonesia tahun 2012, Fakultas Kedokteran UII Yogyakarta, 2012.

Kusmiran, Eny, Reproduksi Remaja dan Wanita, Jakarta:Salemba Medika, 2012.

McGraw-Hill, Higher Education, New York: The McGraw-Hill Companies, 2007.

Melindungi Anak dari Seks Bebas, Jakarta: Raja Grasindo, 2010

Nurcahyo, Heru, Ilmu Kesehatan: Untuk Sekolah Menengah Kejuruan, Jakarta: Direktorat Pembinaan SMK Direktorat Jenderal Manajemen Pendidikan Dasar dan Menengah, 2008

Pratiwi, D.A., dkk, Buku Penuntun Biologi SMA 2, Jakarta: Bumi Aksara.

Samad, Duski, "Pandangan Islam tentang Hak Kesehatan Seksual dan Reproduksi" dalam http://tarbiyahiainib.ac.id/dekan/artikel/601pandangan-islam-tentang-hak-kesehatan-seksual-dan-reproduksi, diakses 27 Maret 2016.

Saptiawan, Sugihastuti Itsan Hadi, Gender dan Inferioritas Perempuan, Yogyakarta: Pustaka Pelajar, 2010.

Shintawati, Rita, "Kesehatan Reproduksi", dalam http://file.upi.edu/Direktori /FPMIPA/JUR._PEND._BIOLOGI/196812012001122-RITA_ SHINTAWATI/RITA-2/KESEHATAN_REPRODUKSI.pdf, diakses tanggal 27 Maret 2016.

Suhandjati, Sri Islam menentang Kekerasan terhadap Istri, Yogyakarta: Gama Media, 2004.

ToR, Lokakarya Hak Kesehatan Seksual dan Reproduksi (HKSR) bagi Tokoh Adat dan Tokoh Agama di Kota Padang. LP2M, 20-21 Mei 2015, dalam http://tarbiyahiainib.ac.id/dekan/artikel/601-pandangan-islam-tentanghak-kesehatan-seksual-dan-reproduksi, diakses 27 Maret 2016.

Undang-Undang Kesehatan dan Rumah Sakit, Yogyakarta: Pustaka Yustisia, 2010. 
UU Kesehatan No 23 Tahun 1992.

Uyun, Zahrotul, "Peran Orang Tua dalam Pendidikan Kesehatan Reproduksi", Prosiding Seminar Nasional Parenting, 2013.

Widyowati, Asih, "Islam dan Kesehatan Reproduksi", 2009, dalam www. fahmina.or.id/penerbitan/warkah-al-basyar/534-islam-dan-kesehatanreproduksi-html, diakses 27 Maret 2016.

Zahrotul Uyun, Peran Orang Tua dalam Pendidikan Kesehatan Reproduksi, Prosiding Seminar Nasional Parenting 2013. 
